\title{
Nemzeti Alaptanterv
}

Az alábbiakban szemelvényeket közlünk a 2020. január 31. napján megjelent a Nemzeti alaptanterv kiadásáról, bevezetéséröl és alkalmazásáról szóló 110/2012. (VI. 4.) Korm. rendelet módositásáról szóló 5/2020. (I. 31.) Korm. rendeletből. A szemelvények célja, hogy az új Nemzeti Alaptanterv alapvetését, alapelveit, céljait és értékrendi kötődését bemutassa. A megjelent Kormányrendelet célja egyrészt az intézményvezetők pedagógusok eligazítása, másrészt az oktatás technikai kereteinek biztosítása is volt, így rengeteg technikai információ és részlet szerepel benne. Ezek közlésétől most eltekintünk. (Amennyiben valaki érdeklődik a teljes, mintegy 300 oldalas anyag iránt, az az interneten több helyen fellelhető. Hivatalos forrásként ajánljuk az http://njt.hu internetes címen elérhető Nemzeti Jogszabálytár szolgáltatást.)

Az anyag megszerkesztése során törekedtünk arra, hogy az eredeti szövegen ne változtassunk. (Emellett viszont terjedelmi korlátok miatt elöfordult az, hogy nem csak teljes jogszabályi szakaszokat, hanem akár csak a szövegből bekezdéseket, illetve egyes bekezdésekből mondatokat töröltünk.) A technikai részletekre vonatkozó anyagokat töröltük, illetve a jogszabályi struktúrára vonatkozó számozások és hivatkozások helyett egy logikus és jobban követhető, jelen szemelvények struktúrájához illeszkedő számozást alkalmaztunk. (Amennyiben a jogszabályi hivatkozás szöveg közben jelent meg, és a szöveg egyéb részei miatt az adott részletet közlésre érdemesnek ítéltük, akkor a szöveg hűségének megörzése érdekében ezen hivatkozásokat változatlanul hagytuk.)

Vertetics Ádám

vendégszerkesztő

\section{ALAPVETÉS}

A Nat a magyar kulturális és pedagógiai örökség gyökereiből táplálkozik, annak hagyományaira épül. A Nat lefekteti a köznevelés elvi és tartalmi alapjait és kereteit, azaz meghatározza az alapmüveltség kötelezően közvetítendő tartalmait az alap- és középfokú oktatási intézmények számára, beleértve a különleges bánásmódot igénylő tanulókat ellátó intézményeket is. A Nat a köznevelés szemléleti alapjainak meghatározásával kiegészíti a gyermekek, tanulók családban megvalósuló nevelését, erősíti ezzel a hazához és a nemzet történelméhez való kötődést, a generációk közötti kapcsolatot, a közös kulturális gyökereket, az anyanyelv használatát. Így rögzíti azt a minden magyar emberben közös tudást, amely megalapozza a nemzeti identitást. 


\section{A MÜVELTSÉGI TERÜLETEK ANYAGAI}

\section{MAgYAR NYELV ÉS IRODALOM}

A Kárpát-medencei magyarság kultúrájának, nemzeti identitásának egyik legfontosabb alapja az anyanyelve és az ezen a nyelven megszólaló irodalma. Nyelv és irodalom: nemcsak hagyományt teremtenek, hanem folyamatos változásukkal jelent és jövőt is alakítanak. A magyar nyelv és irodalom tantárgyak kiemelten fontos területei a nemzeti öntudatra, önazonosságtudatra nevelésnek. Nyelvünk, közös történelmünk, keresztény alapú vallási és múvészeti hagyományaink összekötnek bennünket: korokat, alkotókat, befogadókat és műveket. Egy kulturális hagyományhoz tartozunk, egy nemzet vagyunk. Ezért a magyar nyelv és irodalom tantárgyak a Kárpátmedencei magyarság irodalmát, szellemi örökségét egységesen és egységben kezelik.

Az irodalomtanításban kiemelt szerep jut azoknak az alkotóknak, akik igazodási pontként erkölcsi magatartásukkal, kiemelkedően magas szintű életművükkel alapvetően határozták és határozzák meg a magyar közgondolkodást. Az irodalmi alkotásoknak értékközvetítő funkciójuk van. A magyar irodalom tantárgy tananyaga olyan normatív értékeket közvetít, amelyek a társadalom döntő többségének értékvilágát tükrözik.

A magyar irodalom oktatása folyamatosságában, az egyetemes irodalom pedig szigetszerüen, a legjelentősebb alkotók és alkotások bemutatásával történik.

$\mathrm{Az}$ irodalmi müvek nyelvileg megformált esztétikai alkotások, melyek beágyazódnak a magyar és az európai kultúrába, így egymással is párbeszédbe tudnak lépni, létrehozva a közös gondolkodást és motívumkincset. Az irodalom azonban nem csak szöveg, és a nyelv sem azonosítható csupán szövegalkotó elemeivel és hatásaival. Az irodalmi alkotások morális, kulturális értékeket örökítenek és teremtenek. Történelmi, személyes tapasztalatokat, bölcseleti felismeréseket hagyományoznak. Létük és hatásuk messze meghaladja a kommunikációs eszköz és a fikciós esztétikai teljesítmény funkcionálisan értelmezett szerepét. Gondolkodásunk, önkifejezésünk, személyes és nemzeti identitásunk kialakításának feltételei és eszközei: „... nemzeti hagyomány és nemzeti poézis szoros függésben állanak egymással." (Kölcsey).

$\mathrm{Az}$ irodalmi müvek olyan erkölcsi, történelmi, érzelmi konfliktusokkal szembesítik az olvasót, melyekben saját jelenüket, benne közösségi és személyes konfliktusaikat is felismerhetik, és amely felismerések a tanulók morális, esztétikai és érzelmi fejlődésének is eszközei. Az anyanyelvi kommunikáció fejlettségének meghatározó szerepe van a nyelvi, a kulturális és a szociális kompetenciák alakításában, fejlesztésében, az érzelmi nevelésben, a tanulás teljes folyamatában.

A magyar nyelv és irodalom kiemelt szerepet tölt be a tantárgyak sorában: az olvasottság, a nyelv rendszerszerü ismerete, tudatos alkalmazása a differenciált szövegértés alapja, az irodalmi szövegek elemzése a szövegek jelentésszerkezetének megértéséig vezet el, ezek pedig lehetővé teszik az összetett, elvont gondolkodási müveletek elsajátítását, majd alkalmazását. Ezáltal a többi tantárgy tanulásának, később a társadalmi beilleszkedésnek és boldogulásnak is feltételei, segítői. Az irodalmi müvek az egyetemes emberi értékeket és normákat (közjó - egyéni boldogság; hazafiság -, individualizmus, igazság, szépség, jóság, stb.) közvetítik, ezért az irodalom, mint tantárgy lehetőséget ad a tanulóknak arra, hogy ezeket az értékeket, azok állandóságát, illetve a koronként bekövetkező átértelmezését megismerjék.

A sikeres anyanyelvi és irodalmi oktatás kihagyhatatlan szereplője a tanár. Viselkedése, a szakma iránti elkötelezettsége, személyes példamutatása önmagában modell a tanulók számára. 
A tanár tanít, nevel, fejleszt, irányít és segít. Hagyományt és tudást ad át, segíti a tanulókat, hogy azokat maguk is felfedezzék, megteremtsék saját kognitív struktúráikat, elkészítsék önálló olvasataikat. Ne csak befogadók legyenek, hanem mérlegelö, problémaérzékeny gondolkodású, kreatív értelmezők is. A müveltség, a strukturált tudás átadása alapvető feltétele annak, hogy a tanulók megtanuljanak önállóan gondolkodni és tanulni. Az értékközvetítés pedig elengedhetetlenül szükséges ahhoz, hogy a mérlegelő gondolkodás képességének segítségével a saját értékvilágukat megalkossák, és ez számukra intellektuális és emocionális élményt jelentsen.

A magyar nyelv- és irodalomtanítás egyidejűleg müveltségközvetítést, kompetencia- és személyiségfejlesztést, morális és érzelmi nevelést is jelent. A kompetenciafejlesztés az önálló tudás kialakításában, a közösségbe való beilleszkedésben nyújt segítséget. A morális és érzelmi nevelés - a kompetenciák fejlesztésével együtt - lehetőséget teremt arra, hogy a tanuló átgondolt ítéleteket alkosson, képes legyen sokoldalúan megindokolni véleményét vagy éppen változtasson azon, hogy müvelt, kiegyensúlyozott, harmonikus személyiségként szűkebb közösségének felelős tagja legyen.

A magyartanítás alapelve, hogy nincs kitüntetett didaktikai modell, tanítási, értékelési mód. A tanár szabad döntése, szakmai felelőssége, hogy az adott tananyaghoz adekvát módszertani, értékelési módot válasszon, hogy órái élményt adók legyenek.

A magyar nyelv és irodalom tantárgyak kötelező törzsanyagában csak lezárt, biztosan értékelhető életmüvek szerepelnek. Ezen felül, a választható órakeret terhére a tanár szabadon beilleszthet kortárs alkotókat, müveket a tananyagba.

\section{IDEGEN NYELV}

A tudásalapú társadalomban a nyelvtudásnak kiemelt társadalmi, kulturális és gazdasági jelentősége van. A nevelési-oktatási rendszer feladata ezért az egyén fejlődésében is kulcsfontosságú nyelvtudás és ezáltal a személyes és a szakmai fejlődés tágabb terének biztosítása. Az idegenynyelv-tanítás és -tanulás a nyelvtudás megszerzésén túl hozzájárul a megismerő folyamatok fejlődéséhez, más tanulási területek fejlesztési céljainak és nevelési feladatainak megvalósításához. A nyelvtanulás során közvetített ismeretek segítik az adott nyelvet használó emberek megismerését, az egyes kultúrák, valamint az azok közötti eltérések megértését, a nyitott és befogadó életszemlélet kialakítását. Az idegen nyelvek ismerete hozzájárul továbbá az érdeklődő, tájékozott nyelvtanulói magatartás kialakításához, és fejleszti a nyelvet tanuló és nyelvet használó anyanyelvi kompetenciáit is. A nyelvtudás és a nyelvhasználat segítségével elért tudás erősítheti a saját nemzeti azonosságtudatot, valamint az európai közösséghez tartozás érzését. Az idegennyelv-tudás lehetővé teszi a társadalmi és tanulási célú mobilitást, valamint növeli az információhoz való hozzáférés lehetőségét, és csökkenti az esélyhátrányokat. Az egyéni előnyök mellett a használható nyelvtudásnak számos társadalmi haszna is van. Az idegen nyelvek ismerete a tudásalapú társadalomban elengedhetetlen. Jelentős szerepe van a körülöttünk lévő világ múltjának, jelenének és jövőjének megismerésében, hozzájárul a tanuló jövőbeni munkavállalói kompetenciáinak sokrétü fejlesztéséhez.

A mai kor egyik fontos nyelv- és oktatáspolitikai célkitűzése az egyéni többnyelvűség fejlesztése, amelyhez nagymértékben hozzájárul az intézményes idegennyelv-oktatás. Fontos, hogy a tanított nyelvek ne különálló tantárgyakként jelenjenek meg, hanem a többnyelvüség kontextusában, azaz a nyelvtanárok építsenek a nyelvtanulók már korábban megszerzett nyelvi kompetenciáira, nyelvtanulási stratégiáira, valamint a nyelvek közötti hasonlóságokra. Ily módon lehetővé válhat az idegennyelv-oktatásban az integrált, nyelveken és kultúrákon 
átívelő szemlélet, elősegítve ezzel a nyelvi tudatosságot és előkészítve további idegen nyelvek későbbi elsajátítását.

Az idegen nyelvek tanítása során figyelembe kell venni a nyelvtanulók más tantárgyak tanulása során szerzett ismereteit, már meglévő anyanyelvi és idegen nyelvi tudását, valamint tanulási és nyelvtanulási stratégiáit. Ezek az egyes tantárgyak között átvihetők, megerősítve ezzel a tudásintegrációt, valamint a tantárgyakon átívelő komplex gondolkodás fejlesztését. Mind az élö, mind a klasszikus idegen nyelvek ismerete olyan tartalmakhoz nyitja meg az utat, amelyek más tanulási területek elmélyülését segítik, és a hatás a másik irányban is döntő fontosságú: az új, a tanulók számára motiváló célnyelvi tartalmak fejlesztik a nyelvtudást és elöremozdítják a nyelvtanulást.

A sikerben fontos szerepet játszik az önálló nyelvtanulásra való tudatos felkészítés is. A hatékony és eredményes idegennyelv-tanításhoz és - tanuláshoz, az egyénre szabott oktatáshoz elengedhetetlen a 21. századi modern eszközök és tartalmak bevonása.

Az idegen nyelv tanulási terület két tantárgyat ölel fel: az élő és a klasszikus idegen nyelvet.

\section{II/1. ÉLÖ IDEGEN NYELV}

A modern élő idegennyelv-oktatás elsődleges célkitüzése a nyelvtanulók nyelvi cselekvőképességének fejlesztése. Ennek értelmében a nyelvtanuló képessé válik arra, hogy a nyelvet kommunikációs céljainak és igényeinek megfelelően valódi szituációkban tudja használni. A tevékenységközpontú élő idegennyelv-oktatás a tanuló-központúságot szem előtt tartva a tanulók számára életkorukkal, illetve érdeklődésükkel összhangban lévő helyzeteket teremt. A cél az, hogy a tanulók olyan valós, a gyakorlatban is alkalmazható nyelvtudást érjenek el intézményes keretek között, mely lehetővé teszi a felsőfokú intézményben való továbbtanulást, felhasználható ismeretszerzésre, szórakozásra, személyes és szakmai céljaik elérésére mind természetes, mind pedig digitális térben. Az idegennyelv-tanítás során a tanulók tehát olyan nyelvhasználók, akik azért tanulják az idegen nyelvet, hogy azt később személyes és választott szakmájukkal összefüggő helyzetekben alkalmazni tudják.

Az élő idegen nyelv ismerete által a tanulók megismerik és megértik az adott nyelvet használó embereket és kultúrákat, és erre építve nyitottabbá, megértőbbé, érdeklődőbbé és tájékozottabbá válnak. Ez hozzájárul személyes és társas kompetenciájuk fejlődéséhez, amely mind az iskolában, mind magánéletükben segíti majd őket további nyelvtanulási és egyéb céljaik elérésében. A nyelvtanulás emellett hatékonyan fejleszti a tanulási és gondolkodási stratégiák beépülését a tanulók tanulási kompetenciájába, valamint jelentős szerepet játszik a tantárgyak közötti tudásintegrációban is. A tantárgyakon átívelö, interdiszciplináris szemlélet segítségével a tanulók az idegen nyelv tanulása során fel tudják használni a más tantárgyak keretében szerzett ismereteiket, valamint építhetnek nyelvtudásukra más tantárgyak tudásanyagának bővítése során.

Társadalmi szinten az élö idegen nyelvek használható tudása és az idegen nyelvi kommunikáció csökkenti az esélyhátrányokat, és növeli az információk egyenlő elérésének esélyét. Az élő idegen nyelvek mindezeken túl lehetőséget kínálnak a nemzetközi kapcsolatépítésre és a tanulási célú mobilitásra is. 


\section{II/2. KLASSZIKUS IDEGEN NYELV}

A klasszikus idegen nyelvek esetében a tanulás társadalmi hasznossága különbözik az élő idegen nyelvekétől. Míg az élő nyelv vonatkozásában az a cél, hogy a tanulás során megszerzett nyelvi készségek a gyakorlatban, tehát hétköznapi, iskolán kívüli tevékenységek során közvetlenül hasznosuljanak, azaz a nyelvtanuló a nyelvet ismeretszerzés és kommunikáció céljaira használja, a klasszikus nyelvek tanítását úgy kell megtervezni, hogy a tanulók kisebb része fogja csak az órán megszerzett készségeket közvetlen kommunikációs eszközként használni. A klasszikus nyelvek ismerete több hivatásban közvetlenül hasznosul, és az információszerzés eszközévé válik.

Egy klasszikus nyelv tanulása három, egymással nagyjából egyenrangú területen fejleszti a képességeket: az adott klasszikus nyelv ismerete, a nyelvet hordozó kultúrához kapcsolódó tapasztalatok és az általános nyelvi kompetenciák.

A klasszikus nyelvek tanulója a klasszikus kultúrára vonatkozó ismeretei révén felismeri, hogy a különböző civilizációk történetileg kialakult és változékony rendszerek, melyeket csak az elvonatkoztatás és az önreflexió eszközeivel értelmezhetünk. A viszonyítás fontosságának megértése hozzájárul a saját kultúra mélyebb megértéséhez is. A klasszikus nyelvek ismerete ezen túlmenően az európai és benne a magyar művelődés hagyományainak mélyebb megismeréséhez vezet, segít megérteni a múltat mint a jelen elözményét, erősíti a kulturális identitást.

A klasszikus nyelvek oktatása a nyelvet elsődlegesen nem kommunikációs eszköznek, hanem információs rendszernek tekinti, ezért a közvetlen kommunikáció helyett a hangsúlyt a grammatikai jelek jelentéshordozó funkciójának megértetésére és a rendszerszerüség bemutatására helyezi. Ennek tudatosítása és elsajátítása nagymértékben fejleszti az analitikai készséget, amely a nyelvi tudatosság egyik alapfeltétele. Segíti ezáltal az anyanyelv müködésének jobb megértését, és előkészíti újabb idegen nyelvek elsajátítását.

\section{MATEMATIKA}

A matematika tanulásának legfontosabb célja, hogy a tanuló:

1. megtapasztalja a matematika értékeit, hasznosságát, szépségét;

2. megismerje a matematikai gondolkodás természetét és a matematika alapvető sajátosságait;

3. fejlessze a szövegértését, a szövegalkotó és absztrakciós képességét a matematika nyelvének és szimbólumainak szóbeli és írásbeli alkalmazása során;

4. fejlessze a számolási készségét, a modellezési, a problémamegoldó és döntési képességét;

5. fejlessze a logikus, pontos, kreatív, mérlegelő, stratégiai és rendszerező gondolkodását;

6. alkalmazható tudásra tegyen szert.

\section{TöRTÉNELEM ÉS ÁLLAMPOLGÁRI ISMERETEK}

A tanulási terület a történelem, az állampolgári ismeretek, valamint a hon- és népismeret tantárgyakat foglalja magában. Középpontjában az emberi civilizáció - és annak részeként a magyarság - által létrehozott kulturális, társadalmi, politikai és gazdasági eredmények bemutatása, emberek és közösségeik viszonyának tanulmányozása áll.

A történelem az emberi közösségeknek a múltról alkotott tudása; egyfelől az emberekkel megtörtént eseményekről tanúskodó különböző források és bizonyítékok, másfelől az ezekről alkotott interpretációk és vélekedések összessége. 
A történelemtanítás fö feladata olyan ismeretek és értékek közvetítése, valamint kompetenciák elsajátíttatása, amelyek hozzásegítik a tanulót, hogy tájékozott, aktív és elkötelezett állampolgárrá, kisebb és nagyobb közösségeinek felelős tagjává váljék.

$\mathrm{Az}$ állampolgári ismeretek tantárgynak a megszerzett történelmi tudásra szervesen épülő témái és tevékenységei - az alap- és középfokú tanulmányok zárásaként a 8. és 12. évfolyamon - a tanuló számára fontos és hasznos ismereteket ad az állam müködéséről és intézményeiről, valamint a család és az állam gazdasági szerepéről. A tantárgy tudást, kultúrát és normákat közvetít, és a tanulót hozzásegíti ahhoz, hogy hazáját szeretö, önálló és felelős, demokratikus gondolkodású polgárrá, a kisebb-nagyobb közösségek értékalkotó tagjává váljon, valamint ahhoz, hogy ismerje és gyakorolni tudja az aktív és felelős állampolgári léthez szükséges eljárásokat, élni tudjon a társadalmi intézményrendszer nyújtotta lehetőségekkel.

Fő cél a normakövető magatartás és a társadalmi felelősségvállalás megalapozása, a szabadság és felelősség, valamint az alapvető jogok és kötelességek egyensúlyának megismerése.

A hon-és népismeret tantárgy tanulása során a tanuló megismerkedik nemzeti kultúránk nagy hagyományú elemeivel, a magyar néphagyománnyal és a hazánkban élő nemzetiségek kulturális emlékeivel, szokásaival, jelenével.

\section{IV/1. TöRTÉNELEM}

Az iskolai történelemtanulás alapját a történettudomány, valamint a hagyomány által legfontosabbnak elismert történetek, tények, személyek, események, folyamatok és jelenségek megismerése adja. A történelmi ismeretek egyfelöl megalapozzák a történelmi müveltséget, amely a tanulót hozzásegíti nemzeti identitása erősítéséhez, valamint ahhoz, hogy azonosulni tudjon kultúránk alapértékeivel. Másfelöl a történelem ismerete alapvető feltétele annak is, hogy a tanulóban kialakuljon a történelemről, illetve a társadalmi kérdésekről való árnyalt gondolkodás és kommunikáció képessége. A történelemtanulás során a tanuló különböző tevékenységeket, müveleteket végez, így elsajátítja azokat a kompetenciákat, amelyek hozzájárulnak ahhoz, hogy megértse a múlt és a jelen társadalmi, politikai, gazdasági és kulturális jelenségeit.

A történelem természete szerint értelmező jellegü, a tényekről alkotott különböző vélemények szükségszerüen vitákat eredményeznek. A történelemtanulás során ezek a viták arra ösztönzik a tanulót, hogy elgondolkodjon az emberi értékekről, illetve az élet alapvető dilemmáit megjelenítő olyan fogalmakról, mint például az igazságosság, hűség, hatékonyság, empátia és felelősség. A viták úgy szolgálhatják a történelemtanulást, ha a tanulóban világossá válik a történelmi tény és interpretáció közötti különbség, illetve ha megerősödnek benne társadalmunk és európai, zsidó-keresztény gyökerü civilizációnk alapértékei.

A történelemtanítás egyik irányítóelve, hogy a magyar történelmet kontinuitásában, az európai, illetve egyetemes történelmet szigetszerüen tárgyalja. A történelem tantárgy tantervének középpontjában a magyar nemzet és Magyarország története áll. Ez a témák arányán, az egyes témák részletezettségén túl abban is megmutatkozik, hogy több általános európai jelenség is konkrét magyar példákon keresztül kerül bemutatásra. Ennek révén a tanuló a magyar történelmi jelenségeket elsősorban nem általános modellek alapján, hanem a konkrét történelmi helyzet jellegzetességeit figyelembe véve tanulmányozhatja. Ez a megközelítés hozzásegíti a tanulót, hogy megértse és méltányolja a magyarság, a magyar nemzet, illetve Magyarország sajátos helyzetéből adódó jelenségeket és folyamatokat, így alakulhat ki benne a tényeken alapuló reális és pozitív nemzettudat. 
A történelemtanuláshoz kapcsolódnak a tantervi tartalmakon és a tanórai munkán kívül a nemzeti ünnepek és emléknapok is, amelyek iskolai megrendezése segíti a sorsfordító események felidézését, a kollektív emlékezetben való rögzítését, az emlékezetkultúra kialakítását és ápolását.

\section{IV/2. ÁLLAMPOLGÁRI ISMERETEK}

A globalizáció korában az ember és a magyar nemzet számos új kihívással szembesül. Az egyénnek olyan kérdésekre kell válaszokat találnia, olyan problémákra szükséges megoldásokat keresnie, amelyek befolyásolják, esetenként pedig meghatározzák lehetőségeit, mindennapi életének alakítását, lokális és tágabb környezetét egyaránt. Az emberi létezésre, az egyén és a közösség viszonyára, a társadalmi változásokra vonatkozó válaszoknak nemcsak az egyéni akaratok, érdekek érvényesítése, hanem a társadalom alapegységét jelentő család, a lokális közösségek és a nemzet jövőjének alakítása szempontjából is jelentősége van.

A tantárgy civilizációs értékeket és mintákat közvetít, erősíti a felelősségtudatot és a nemzethez tartozás érzését. Ennek érdekében segíti a szituációhoz igazodó kommunikáció kialakítását, a másik ember gondolatainak, véleményének megértését, az együttmüködés lehetőségeinek feltérképezését és közösségformáló erejének megtapasztalását, a hazafias érzés kialakítását, az alapvető honvédelmi ismeretek elsajátítását, a nemzedékek közötti párbeszéd erősítését, valamint a környezeti, gazdasági-pénzügyi fenntarthatóság feltételeinek kiemelését.

A tantárgy keretében a tanuló elsajátítja a tudatos és felelős állampolgári léthez szükséges alapvető ismereteket, a szociális kompetenciák fejlesztése révén megismeri és gyakorolja azokat az eljárásokat, készségeket, amelyek a társadalmi részvételéhez, mindennapi boldogulásához szükségesek. A tanuló megismeri és megérti, hogy a haza védelme nem csak a fegyveres erők feladata, hanem minden magyar állampolgáré, ezért a honvédelem ügye a lehető legszélesebb nemzeti egységet képviseli.

A jogi kultúra fejlesztése, az alapvető emberi jogok értelmezése, a szabadságértékek kiemelése, a társadalmi normák, a szabadság és felelősség kapcsolatának tudatosítása segíti az autonóm személyiség kialakulását. A saját vélemény kifejezése, a társak gondolatainak, véleményének megértése, a vitakultúra fejlesztése a demokratikus attitüd megalapozásához járul hozzá.

\section{IV/3. HON- ÉS NÉPISMERET}

A globalizációs folyamatok térhódítása mellett egyre nagyobb szükség van arra, hogy a felnövekvő nemzedék stabil értékrenddel, erős gyökerekkel rendelkezzen, ismerje és becsülje nemzeti értékeinket, alakuljon ki benne a nemzethez tartozás tudata. A nemzeti és családi hagyományok, értékek elhalványulása, a nevelés folyamatának háttérbe szorulása miatt a hagyományos értékrend közvetítését, a szülőföldhöz kötődés megerősítését, a nemzeti értékek megismertetését az iskolának is hangsúlyosan fel kell vállalnia.

A tantárgy lehetőséget ad a tapasztalati úton történő tanulásra, az ismeretek élménypedagógiai módszerekkel történő elsajátítására. Fontos szerepet kap a saját gyüjtőmunka, a szükebb és tágabb szülöföld értékeinek, hagyományainak tanári támogatással történő felfedezése, a megismert néphagyományok feldolgozása, megjelenítése egyéni és csoportmunkában. Az önálló ismeretszerzésben szerepet kap a család és a tágabb rokoni, szomszédi környezet. Az idősebb korosztály ismereteinek befogadása erősíti a nemzedékek közötti párbeszédet, formálja a nemzethez, a családhoz, valamint a szükebb és tágabb közösséghez tartozás tudatát. A különböző generációk 
ismereteinek, életmódjának felfedezése fejleszti a több nézőpontú gondolkodást, a mérlegelés képességét. A tantárgy a múltra támaszkodva erősíti a tanulóban a családja és a nemzete jövőjéért érzett felelősségtudatot.

A tantárgy keretében a tanuló megismeri, megérti a hagyományos gazdálkodó életmód szemléletét, amely a természettel való harmonikus együttélésre alapul, valamint a városi polgári életforma hagyományait. Mintát kap a közösségi életforma működésére, az egymásnak nyújtott kölcsönös segítség megvalósítható formáira. Részese lehet a játékok segítségével megvalósuló nevelési folyamatnak, amely életkori sajátosságainak megfelelően nyújt mintát a hagyományos, családon belüli szerepkörök, feladatkörök elsajátítására.

A hon- és népismeret a hagyományos népi élet társadalmi jelenségeinek személyes megközelítésével, a magyar népszokások megismerésével megalapozza a jelenkori társadalom felépítésének, működésének megértését, összehasonlítási alapot biztosít, és lehetőséget teremt a változások felfedezésére, az ok-okozati összefüggések feltárására, ezáltal a tanuló elkötelezetté válik a közösségért végzett munkára és a felelősségvállalásra.

\section{ETIKA / HIT- ÉS ERKÖLCSTAN ${ }^{1}$}

A tantárgy középpontjában az erkölcsi nevelés áll, amely a tanuló erkölcsi érzékének és erkölcsi gondolkodásának fejlesztését jelenti. A tanulás folyamán az erkölcsi kategóriák jelentéstartalmának folyamatos gazdagítása, szükség esetén újraértelmezése, élethelyzetekre vonatkoztatása, valamint az ezekből következő etikai kérdések felvetése történik. A tananyag alapvető értékeket közvetít: a segítés, megértés, együttérzés, törődés, szabadság, felelősség, igazságosság, becsületesség, méltányosság, tolerancia, önazonosság. Ezek a tanuló lelkiismeretének fejlődését szolgálják. A témák feldolgozása a tanulót megfontolt döntésre, kulturált véleményalkotásra és felelős tevékenységre készteti.

A tanulóközösség tevékenységei mintát nyújtanak arra, hogy milyen érzelmi-, érdekkonfliktusok és viselkedésmódok segítik vagy akadályozzák az együttmüködést. Az ajánlott tantárgyi tartalmak és tanulói tevékenységek olyan képességeket is fejlesztenek, melyek a tanulót az életvezetésében hatékonnyá és tudatosabbá, társai és környezete problémái iránt érzékenyebbé teszik, erősítik identitását, aktív társadalmi cselekvésre késztetik és segítik a nehéz helyzetek megoldásában.

A tantárgy - jellegénél fogva - elsősorban a személyes és társas képességeket, illetve a tudatos társadalmi részvételt és felelősségvállalást fejleszti. Fő feladata olyan ismeretek és értékek közvetítése, valamint kompetenciák elsajátíttatása, amelyek hozzásegítik a tanulót, hogy tájékozott, aktív és elkötelezett állampolgárrá, kisebb és nagyobb közösségeinek felelős tagjává váljék.

Az etika tanulása során a tanuló megismerkedik a magyar, az európai és a világtörténelem etikailag is fontos eseményeivel, jelenségeivel, folyamataival és szereplőivel. Ez jelentős mértékben elősegíti, hogy a tanuló megismerje és elsajátítsa azt a kulturális kódrendszert, amely lehe-

\footnotetext{
${ }^{1}$ A nemzeti köznevelésről szóló törvény rendelkezései szerint az általános iskola 1-8. évfolyamán az etika tantárgy oktatása kötelező tanórai keretben történik. A hit- és erkölcstan oktatás tartalmát az egyházi jogi személy határozza meg.
} 
tővé teszi számára identitása, valamint a magyar nemzet és a keresztény, keresztyén normarendszeren alapuló európai civilizáció iránti elkötelezettsége kialakítását és megerősítését.

Tudatosítja a tanulóban, hogy elsősorban nemzete saját hagyományainak, értékeinek megismerése, elsajátítása és gyakorlása mellett válhat nyitottá a velünk élö nemzetiségek, vallási közösségek, a szomszéd és a rokon népek, valamint a világ többi népének kultúrája, az egyetemes értékek iránt is.

Az etika tantárgy alapvető célja annak felismertetése, hogy a kulturális hagyományokban gyökerező etikai elvek, társas szabályok, szocio-emocionális készségek miként járulnak hozzá az egyéni és közösségi identitás formálódásához, stabilitásához, valamint az egyének és csoportok közti együttmüködés megteremtéséhez. A tanuló elsősorban az európai vallásokkal való megismerkedésen keresztül, az elsajátított információkra reflektálva tanulmányozza, hogy az egyes hitrendszerek milyen értékek mentén kínálnak értelmezési keretet az emberi létezésre vonatkozó gondolkodáshoz. A társadalmi együttélést szabályozó, egymástól eltérő jogrendszerek egyes elemeinek értékközpontú vizsgálata elősegíti a társadalmi csoportok és egyének érdekérvényesítésének megértését.

\section{TERMÉSZETTUDOMÁNY ÉS FÖLDRAJZ}

A tanulásterület az anyagi világ jelenségeit, az élővilágot és földrajzi környezetet a természettudományok módszereivel vizsgálja, valamint megjelenít ezzel összefüggő társadalomtudományi és gazdasági ismereteket is. Megalapozza a természettudományos müveltség mindennapi életben felhasználható képességeit és ismereteit, elősegíti a természettudományos és müszaki életpályák választását. A tanulás-tanítás tervezése során figyelembe kell venni a tanulónak a természetes gyermeki kíváncsiságtól a tudományos megismerés képességének megszerzéséig jellemző személyiségfejlődését. A tanulók aktív részvételére épülő tanulási módszerekkel a tartalmi tudás és a képességek együttes fejlesztését, a tudás közösségi interakciókban történő építését kell lehetővé tenni. Ebben nagyobb teret kaphat a tanuló érdeklődése, aki a vizsgált jelenségeket több tudományterület összefüggésében elemezheti, felhasználva az információs és kommunikációs technológiák adta lehetőségeket. A természettudományos müveltség az alapvető fogalmak és elméletek mellett a tudomány természetéről szerzett tudást és a mindennapi életben alkalmazható vizsgálati és probléma-megoldási készségek fejlesztését is magában foglalja olyan területeken, mint az egészségtudatosság, a természeti és épített környezet védelme, vagy a tudatos technológiahasználat. A tanulásterület fontos részét képezik a természettudomány alkalmazásának etikai kérdései, amelyek kapcsolódhatnak az etika tantárgy releváns tartalmaihoz. A természettudományos és műszaki életpályákra való felkészülés, az MTMI kompetenciák fejlesztése részletesebb tartalmi tudást és mélyebb megértést kíván, ezt a tanulók érdeklődése, igénye és képességei szerinti emelt szintü képzésekkel és tematikus programokkal lehet biztosítani.

\section{VI/1. KÖRNYEZETISMERET}

A környezetismeret tantárgy a természettudomány és földrajz tanulási terület bevezető tantárgya. A tantárgy keretein belül végzett, aktív tanulásra épülő tevékenységek olyan tapasztalatokat tesznek lehetővé a tanulók számára, amelyek illeszkednek életkori sajátosságaikhoz, kognitív fejlődésükhöz, és belső motivációjukra támaszkodnak. Ezek a tevékenységek támogatást nyújtanak ahhoz, hogy a tanulók megismerjék testi jellemzőiket, a szükebb és tágabb környezetüket, 
megértsék a fizikai tulajdonságaik mentén és a környezetben zajló változásokat, ráébredjenek alapvető ok-okozati összefüggésekre. Az olyan tevékenységek, mint a megfigyelés, leírás, összehasonlítás, csoportosítás, mérés, kísérletezés, a tanulók kíváncsiságára támaszkodnak, és megalapozzák a tanulás későbbi szakaszaiban megjelenő tantárgyak tudásbázisának kialakítását. A tantárgy tanulása erősíti az ember és a természet, az élő, az élettelen és a kultúra által létrehozott környezet iránti érdeklődést, felkelti a tanulók motivációját a természettudományok és a földrajz tárgykörébe tartozó problémák egyre mélyebb megismerése iránt.

\section{VI/2. TERMÉSZETTUDOMÁNY}

A természettudomány tantárgy alapvető szerepet játszik a tudományos és technológiai műveltség kialakításában, a természettudományokkal való ismerkedés korai szakaszában. Összekötő szerepet tölt be az alsó tagozatos környezetismeret és a 7. osztálytól diszciplináris keretek között oktatott természettudományos tárgyak (biológia, fizika, földrajz, kémia) között. Ugyanakkor a tantárgynak van egy horizontális vetülete is, hiszen a természettudományi tanulmányok sok esetben építenek a más tantárgyak (főleg a magyar nyelv és irodalom, a matematika és a történelem) keretében megszerzett tudásra, készségekre, kompetenciákra.

A fenti megállapításokból kiindulva a természettudomány tárgy négy olyan alapdiszciplína (biológia, fizika, földrajz és kémia) köré szerveződik, amelyek a természeti törvényszerüségek, rendszerek és folyamatok megismerésével foglalkoznak. Ennek megfelelően a természettudomány tárgy célja e komplex tudásanyag integrálása az egyes természeti rendszerek közötti alapvető összefüggések megvilágítása révén.

A természettudomány tanulási-tanítási folyamatában alapvető szerepe van a tanuló számára releváns problémák, életszerü helyzetek megismerésének, amit a tantárgy a felvetett probléma integrált szemléletü tárgyalásával, a tanulók aktív közreműködésével, egyszerü - akár otthon is elvégezhető - kísérletek tervezésével, végrehajtásával, megfigyelésével és elemzésével érhet el. Mindezeket nagyon fontos kiegészíteni terepi tevékenységekkel is, amik nem csupán a természetben történő vizsgálódásokat jelentik, hanem akár városi környezetben is megvalósulhatnak. $\mathrm{Az}$ élményszerü, a tanuló gondolkodásához, problémáihoz közel álló, gyakorlatorientált ún. kontextusalapú tananyag-feldolgozás hatékonyabb, mert az ismeretek rendszerezésével zárul.

A természettudomány tananyaga tehát mindenkihez szól, nem csak azokhoz, akik a későbbiekben komolyabban szeretnének természettudományokkal foglalkozni. Szervesen kapcsolódik a hétköznapi élethez és erősen gyakorlatorientált. Feltárja a természettudományok társadalmunkban és az egyén életében betöltött szerepét. Nem tartalmaz sok ismeretet és fogalmat, viszont annál több gyakorlati jellegű tevékenységet, megfigyelést, tapasztalást épít be. Hagy időt az elmélyült feldolgozásra, az esetleges megértési problémák megbeszélésére, tekintettel van az információfeldolgozás memóriakapacitására, a kognitív terhelésre. Figyel a megfelelö, már részben szakmai nyelvhasználatra és kommunikációra. A tárgy célja inkább a fogalmi megértés, és nem az információk szigorú megtanítása, valódi problémamegoldást kínál. Előnyben részesíti az életszerú természettudományos problémák csoportmunkában (projektmódszerrel, kutatásalapú tanítással) történő feldolgozását. Megfelelően használja a kísérleteket, a terepi foglalkozásokat, megfigyeléseket, melyeknek mindig világos a célja, és a manuális készségek mellett a fogalmi megértést is fejlesztik. Hangsúlyozza a kísérleti problémamegoldás lépéseit, különös tekintettel a várható eredmény becslésére (hipotézisalkotásra). Az ellenőrzés során döntően a megértést, a logikus gondolkodást méri. 


\section{VI/3. BIOLÓGIA}

A nevelés-oktatás alapvető értékeinek közvetítése és az emberkép formálása a tantárgy kiemelt feladata. Erre jó lehetőséget biztosít az a tartalmi és készségfejlesztési kapcsolódás, ami a biológia és a testi-lelki egészségre nevelés, az önismeret, emberismeret, valamint a fenntarthatóság pedagógiája között fennáll. A korábbi évek tanulmányai után a tanulók részletesebben és elmélyültebben foglalkozhatnak az életjelenségek megértésével, az élőlények sokféleségével és az életközösségek müködésével. Az emberi szervezetről szerzett ismeretek fejlesztik a tanulók testképét és önismeretét, hozzájárulnak az egészséges életvitel értékének felismeréséhez, az ezt segítő attitüdök és szokások kialakításához. Az életközösségek vizsgálata, folyamataik azonosítása összekötheti a múlt adatait a jelenben észlelhető változásokkal, amelyből előrejelzés tehető a várható jövővel kapcsolatban is. A fenntarthatóságot a biológiai rendszerekre vonatkoztatva vizsgálják a tanulók, összefüggéseket keresnek az emberi tevékenységgel, a gazdaság és társadalom müködésével is. A tartalmi tudás építése kiegészül a természettudományos vizsgálati és gondolkodási módszerek elsajátításával, amely a mindennapi életben felmerülő problémák vizsgálatában is alkalmazható. A tudomány természetének és működésének megértése és begyakorlása aktív tanulási módszerekkel történik, amely a tanulók együttmüködésére és kommunikációjára alapozódik. Az interaktív tanulás megnyitja a problémaazonosítástól a vizsgálatokon át a magyarázat kereséséig vezető megismerési utat, amelyen többféle nyomtatott és elektronikus információforrás felhasználásával, megfelelő támogatással, de önállóan, az egyéni érdeklődés és tanulási szükségletek figyelembevételével haladhatnak a tanulók. A mindenki által megszerezhető és alkalmazható természettudományos müveltség fejlesztése mellett fontos, hogy különféle tanulói utak nyíljanak az életpálya-építés, a szakirányú továbbtanulás felé is. Ezt szolgálhatja az MTMI alapismeretek beépítése a biológiatanulás folyamatába. A problémamegoldás, kreativitás és innovatív gondolkodás fejlesztésének feltétele a tanulók érdeklődésének fenntartása, az önálló ismeretszerzés képességének erősítése.

\section{VI/4. FIZIKA}

A természettudományok, és így a fizika az emberi megismerés fontos és hatékony eszközei. A természet alaptörvényeinek feltárása, azok alkalmazása világunk jobb megértése, és technikai civilizációnk fejlesztése érdekében közvetlen, életminőségünket befolyásoló előnyökkel jár. A fizikai műveltség alapvető kulturális érték, megörzése és gyarapítása az egymást követő nemzedékek kiemelt feladata, a jövő iránti elkötelezettség megnyilvánulása.

A fizika oktatása során a hangsúly a fizikai gondolkodásmódra, a fizika megismerési módszereire, mindennapi életben való alkalmazhatóságára esik, olyan ismeretekre, melyekre a nem szakirányba továbbtanuló tanulónak is szüksége van. Az oktatási, tanulási folyamat mélyíti a szükséges szakmai ismereteket, támogatja a tudásalkalmazást, összekapcsolja a tantárgyon belüli és a tantárgyak közötti releváns információkat és szervesen épít a jelenségalapú tudásszervezés alapelveire.

A mai korban az információkat, a szakismereteket az egyre könnyebben és hatékonyabban használható digitális adatbázisok biztosítják. Ugyanakkor az adatbázisok sikeres használatához személyes tudásra is szükség van. A természettudományos és mérnöki pályákra készülőknek tisztában kell lenniük az ismeretrendszerek fö struktúrájával, kulcsfogalmainak jelentésével és megfelelő matematikai kompetenciákkal is rendelkezniük kell. 
A tantárgy céljai közt szerepel a fizika természettudományos és általános társadalmi kontextusának kibontása, mely leginkább a tudománytörténet érdekesebb fejezeteinek tanulmányozása révén válik lehetővé. A fizika művelése, mint minden természettudományos tevékenység, müködése és hatásai okán társadalmi jelenség.

\section{VI/5. KéMIA}

A kémia olyan ismeretek, módszerek, eljárások összessége, amelyek ismerete és értő alkalmazása nélkül nem lenne fenntartható az életünk. A kémia által tervezett, fejlesztett molekulák, anyagok teremtik meg az alapját pl. az informatikai lehetőségeknek, épített környezetünk kialakításának, az emberi élet és annak minősége biztosításának. A kémia oktatása során hangsúlyozni kell az új, izgalmas, az emberi élet minőségét javító anyagok felfedezésének, kifejlesztésének célját, utalni kell az orvosbiológiai alkalmazásokra, az ürkutatásra, az elektronikus eszközökben felhasználható új anyagok kialakítására, hangsúlyozni kell a gyógyszerkutatás, a gyógyszeripar és a vegyipar szerepét.

Mély kémiai ismeretekre van szükség a gazdaság számos kiemelt fontosságú területén: például a vegyiparban, a gyógyszeriparban, az atomenergia-termelésben, az egészségügyben, a környezetvédelemben, a minőségbiztosításban vagy éppen a biotechnológiában.

A kémiai ismeretek az anyag tulajdonságaiban bekövetkező változásokhoz, illetve az ezen változásokat alapvetően meghatározó hatásokhoz kapcsolódnak (összetétel, szerkezet, energia, kémiai reakció). Alapvetően azok az elvek, törvények tartoznak ide, amelyek az anyag- és energia-megmaradással foglalkoznak, a változásokat kísérő atomszerkezethez köthetö jelenségek leírását tartalmazzák. A kémia tárgyalásmódjára jellemző, hogy az összetétel és a szerkezet alapvetően meghatározza a tulajdonságokat, illetve az anyagok tulajdonságaiból következtethetünk a szerkezetre, esetleg az összetételre is. Az anyagot felépítő részecskék (atomok, ionok, molekulák) egymáshoz viszonyított elhelyezkedése (halmazszerkezet) és a köztük kialakuló kölcsönhatások határozzák meg az anyagok jellemzőit.

A kémia tanulási-tanítási folyamatában alapvető szerepe van a tanuló számára releváns problémák, életszerű helyzetek során megjelenő kémiai vonatkozások megismerésének, amit a tanuló aktív közremüködésével, egyszerü - akár otthon is elvégezhető - kísérletek tervezésével, végrehajtásával, megfigyelésével és elemzésével célszerü elérni.

A kémia az anyagok tulajdonságainak és változásainak feltárása és leírása mellett a változások mennyiségi viszonyaival is foglalkozik, ezért a kémia tanulása során az alapvető mennyiségekkel való ismerkedés is a tananyag részét képezi.

A kémia tananyaga mindenkihez szól, nem csak azokhoz, akik vegyészek vagy természettudósok akarnak lenni. Szervesen kötődik a hétköznapi élethez és hangsúlyozottan élmény- és alkalmazásközpontú. Feltárja a kémia társadalmunkban és az egyén életében betöltött szerepét. Nem tartalmaz túlzottan sok, a tanulók számára csak nehezen megérthető és feldolgozható fogalmat, ismeretet. Az összefüggések megértésére és a természettudományos gondolkodásmód kialakítására fekteti a hangsúlyt. Hagy időt az elmélyült feldolgozásra, az esetleges megértési problémák megbeszélésére, tekintettel van az információfeldolgozás memóriakapacitására, a kognitív terhelésre. A részecske- és szimbólumszintü fogalmak nem túl korai bevezetése a tananyag megértését szolgálja. A képletek és egyenletek gyakoroltatása pont akkora hangsúlyt kap, hogy a tanuló a mindennapokban elöforduló jelöléseket képes legyen értelmezni. Figyel a megfelelő nyelvhasználatra és a kommunikációra. Célja a fogalmi megértés, valódi problémamegoldást 
kínál, és nem az információk megtanítására törekszik. Az algoritmikus problémák helyett inkább nyílt végü és játékos feladatokat használ. Előnyben részesíti az életszerű kémiai problémák aktív tanulással, lehetőleg csoportmunkában történő feldolgozását.

A testi-lelki egészségre nevelést segíti elő a helyes táplálkozás, valamint a káros szenvedélyek kémiai alapjainak megismerése. Az önismeret és az együttmüködö képesség fejlesztését szolgálják - többek között - azok a kooperatív tevékenységek, amelyekkel a kémia néhány anyagrészét dolgozzák fel a tanulók. A kémiai információk gyüjtése, rendszerbe foglalása és bemutatása fejleszti a kommunikációs kultúrát és a médiahasználatot. A kémiával kapcsolatos pályán dolgozó kutatók és mérnökök munkájának a megismerése hozzájárul a tudatos életpálya-tervezéshez. A híres magyar kémikusok és kémiai Nobel-díjasok bemutatása erősíti a tanulók nemzeti és európai azonosságtudatát, hazaszeretetét. Az emberiség néhány globális problémája (éghajlatváltozás, víz-, levegő- és talajszennyezés) kémiai vonatkozásának tárgyalása hozzájárul a tanulóknak a fenntartható jelen és jövő iránti elkötelezettségének kialakításához és megerősítéséhez.

\section{VI/6. FöLDRAJZ}

Földrajzi, földtudományi és környezeti jelenségek, folyamatok sokasága jellemzi bolygónkat. Ezek különböző tér- és időbeli léptékekben a Föld különböző pontjain jelentkeznek. Egyre összetettebbé váló világunk komplex problémáinak megértése megköveteli az eddigi tanítási, tanulási stratégiák megújulását: a leíró jellegü, ismeretközlö hagyományokkal szakítva, de a szaktárgyi tudást el nem vetve számos, a korábbiakban kevésbé hangsúlyos kompetencia kialakítását és fejlesztését célként megjelölve. A saját tevékenységeken, a hétköznapi megfigyeléseken és tapasztalatokon alapuló földrajztanítás nem pusztán leírja a jelenséget, hanem annak okát és következményeit is feltárja. Mindez a természeti-környezeti és a társadalmi-gazdasági folyamatokat szintetizálva, a jelen eseményein túlmutatva értékelésre, problémamegoldásra, jövőképalkotásra ösztönöz.

A földrajzoktatás során a tanuló megismerheti szükebb és tágabb környezete természeti és társadalmi-gazdasági jellemzőit, a körülötte zajló folyamatokat és ezek összefüggéseit. A földrajz szemléletformáló, szintetizáló tantárgyként olyan, a hétköznapokban használható ismereteket, eszközöket, módszereket ad a tanuló kezébe, amelyek segítik a tájékozódást egyre összetettebbé váló világunkban, és hozzájárulnak ahhoz, hogy felnőtt életében felelös, környezettudatos, aktív állampolgárrá váljon.

\section{MüvÉSZETEK}

A nevelés a teljes emberre irányul, aki test-szellem és lélek egysége, tehát a köznevelés célja nem választható el az élet céljától.

A művészet alapvető emberi szükséglet, a művészi alkotás pedig az ember legősibb kifejezési módja. A művészet köznevelésben betöltött szerepe nem önmagáért való, feladata egyensúlyt teremteni az értelmi-érzelmi intelligencia fejlesztésében.

A tanuló belső világának érzelmi gazdagsága pozitívan hat a gondolkodás, a kreativitás, az emlékezőtehetség képességeire.

A művészeti nevelés önálló tantárgyként az ének-zene, illetve a vizuális kultúra oktatásában valósul meg. 
A tanórai keretek között, mindenki számára elérhető művészeti nevelés célja olyan képességek fejlesztése, melyek elősegithetik a harmonikus társadalmi együttélést, azaz a művészeti tantárgyak a művészet eszközeit a személyiség egészének fejlesztése érdekében használják fel.

A művészeti tanóra egyrészt keretet biztosít a művészet különböző területeinek megismerésén keresztül az érdeklődés felkeltésére, az esztétikai alapfogalmak elsajátitására, ízlésformálásra, másrészt a mérlegelő gondolkodás és a minőségi alkotómunka iránti igény kialakítására.

Ennek eredményeként elérendő cél, hogy a tanulók a magyar kultúrára büszkék legyenek, és kötődjenek szülöföldünk értékeihez.

A Művészetek tanulásterület köznevelésben betöltött feladata tehát a művészettel nevelés, illetve más tanulásterületekkel együtt a képességfejlesztés transzferhatásának kihasználása, testben-lélekben boldogságra és boldogulásra képes generációk felnevelése érdekében.

\section{VII/1. ÉNEK-ZENE}

A zenei nevelés Magyarországon a Kodály Zoltán által megalkotott filozófát követve, tevékenység-központú módszer alapján valósul meg. A magyar zenekultúra évszázados hagyománya, hatalmas dallamkincse bőséges anyagot kínál a zenei oktatás minden szintjéhez. Zenei anyanyelvünk általános műveltségünk megalapozásának és nemzeti azonosságtudatunknak fontos tényezője.

„Mielőtt más népeket akarunk megérteni, magunkat kell megértenünk. Semmi sem alkalmasabb erre, mint a népdal. Erre az alapra épülhet olyan zenei müveltség, mely nemzeti, de lelket tár minden nép nagy alkotásainak. Értékmérőt is kap a népdallal, aki e századok csiszolta tökéletességhez méri, amit hall: nem tévesztik meg többé hamis bálványok..." (Kodály Zoltán)

Az ének-zenei nevelés a tanuló identitástudatának kialakítása és személyiségfejlődése szempontjából kiemelkedő fontosságú. Fontos szerepet tölt be nemzeti örökségünk és identitásunk ápolása a magyar népzene, a magyar tájegységek, azok szokásainak, életének, nevezetességeinek, táncainak megismerésével, mely a családszeretet, a hűség, és a haza iránti elkötelezettség érzését is erősíti. A zenei nevelés akkor lesz eredményes, ha kialakul a tanuló zenei anyanyelve, mely által hazájához, nemzetéhez értelmileg és érzelmileg egyaránt kötödik. Ebben a pedagógus munkájának érdemi szerepe van, melynek hatása életre szóló, túlmutat az iskola falain.

Az ének-zenei nevelés speciálisan olyan készségeket, képességeket, kompetenciákat is fejleszt, melyek hatással vannak egyéb, nem zenei képességekre is (transzferhatás).

Az aktív zenei tevékenységek, mint a közös éneklés, zenélés, alkotás és zenés tematikus projektekben való részvétel, segítik az adott művészeti élmény elmélyülését. Teret adnak az önkifejezés, kreativitás kibontakozásának, és az empátia kialakításának. A zenetörténeti, zeneelméleti és kulturális müveltség a zenei élményekhez, tevékenységekhez kapcsolódóan az értő befogadást és a mérlegelő gondolkodást fejlesztik. A tanuló képes lesz a müvészi gondolatok és az őt körülvevő hétköznapi világ közötti kapcsolatok meglátására, valamint az eltérő látásmódok megértésére és elfogadására is.

Kodály Zoltán zenei nevelési elvei lényegének megfelelően, mely az élményszerzés legfontosabb forrásaként a kóruséneklést nevezi meg, a Nat lehetőséget biztosít a tanórán kívüli zenei tevékenységek - mint a koncertpedagógia, az iskolai néptáncoktatás, népdalkörök, népdalkórusok, kamaraegyüttesek - iskolai keretek közti és azon túli szerveződése számára, melyhez a köznevelés és a kultúrát közvetítő intézmények, szervezetek együttmüködése elvárható és szükséges.

Az ének-zene tanulása elsősorban a készségeket és az ezeket megalapozó képességeket fejleszti. A tanulók nem azonos képességszintről indulnak és nem is azonos eredményességgel vég- 
zik tanulmányaikat. Ezért az értékelés alapja az ének-zene tanulás minden életkori szakaszában alapvetően a tanulói aktivitás, lelkesedés, kooperativitás, illetve a tanulási képességek változása, a tanuló önmagához mért fejlődési szintje kell, hogy legyen.

\section{VII/2. DRÁMA ÉS SZÍNHÁZ}

A dráma és színház tanulása olyan komplex művészetpedagógiai tevékenység része, amely a csoportos játékok együttes élménye révén segíti elő a tanulók alkotó és kapcsolatteremtő képességének kibontakozását; összpontosított, megtervezett munkára szoktatását; testi, térbeli biztonságának javulását; idő- és ritmusérzékének fejlődését; valamint szolgálja ön- és társismeretük gazdagodását; fejleszti az érzékelést, a kommunikációt, a kooperációt. Különösen alkalmas a fogékonyság, a fantázia, az önkifejezés, valamint a tolerancia, az együttműködés, továbbá a konfliktuskezelési képesség és a felelősségvállalás és autonómia kialakítására, a közösségi tudat és az önazonosság erősitésére. A dramatikus tevékenységek egyszersmind fejlesztik a zenei képességeket, a vizuális érzékenységet, a térérzékelést, a testtudatot, a mozgáskultúrát, ily módon integrálják a többi művészeti kifejezési formát is.

A dráma nyelve a színház. A dráma és színház komplex művészeti ismereteket nyújt, és az alkotómunkával együtt járó élmények segítségével hozzájárul a kreatív személyiség kialakításához. A kultúra iránt nyitottságot, esztétikai érzékenységet alakít ki, és a művészetek befogadására, értésére és müvelésére nevel.

\section{VII/3. VIZUÁLIS KULTÚRA}

A vizuális kultúra tantárgy legfontosabb alapelve az aktív tanulói alkotómunkán alapuló gyakorlatközpontúság.

A vizuális nevelés - tantárgyi tanulási eredményeiben is jól megmutatkozó - alapelve továbbá, hogy az egyéni feladatmegoldás mellett megfelelö teret kap a csoportban megvalósított alkotó és befogadó tevékenység, hisz a csoportos feladatmegoldás segíti az önismeretet és önszabályozást, az önértékelést, továbbá a másokra való odafigyelést és elfogadást.

A tárgy tanítása akkor eredményes, ha a tanulók vizuális produktumot hoznak létre. Az eredményes fejlesztés a különböző nevelési-oktatási szakaszok életkori sajátosságainak ismeretében, változatos és játékos módszerek használatával érhető el.

Az alkotó, vizuális önkifejező tevékenység a személyiségfejlesztés egyik legizgalmasabb és legeredményesebb eszköze. Az alkotás felszabadító ereje segíti az érzelmek felfedezését és tudatosítását. A vizuális produktum létrehozása során az elemző, értelmezö, szintetizáló és újszerü megoldásokat kereső tevékenységek az összetett gondolkodási műveletek gyakorlását is lehetővé teszik.

A vizuális kultúra tantárgynak jelentős, el nem hanyagolható szerepe van a sokoldalú, kiegyensúlyozott személyiség fejlesztésében, kialakításában.

A vizuális kultúra tanterv témakörei a tantárgy alapvető részterületeit, a képzö- és vizuális művészetet, a vizuális kommunikációt, valamint a tárgy- és környezetkultúrát részletezik tovább. E részterületek jelzik a tantárgy legfontosabb tartalmait.

A vizuális kultúra jellemzően képességfejlesztő tantárgy, ebből következően a vizuális megismerés eszközként használható más tudományterületek, más tantárgyak tartalmainak feldolgozásához is. 


\section{VII/4. MoZgóKÉPKULTÚRA ÉS MÉDIAISMERET}

Az interperszonális és a tömegkommunikáció, az elmúlt évtizedekben, és különösen az utóbbi években alapvető változásokon ment keresztül, köszönhetően a technikai-technológiai fejlődésnek és az ezzel összefüggésben jelentősen átalakuló fogyasztói magatartásnak. Az audiovizuális művészeti alkotások a permanens digitális-technológiai forradalom következtében a mindennapok szerves részévé váltak a fogyasztói társadalomban. A mozgóképkultúra és médiaismeret tanításának célja az alapvető médiaműveltség megszerzése, különös tekintettel a mozgóképi szövegértés fejlesztésére, a média társadalmi szerepének és működésmódjának feltárására. Olyan képesség- és személyiségfejlesztő eszközrendszer, amely szükséges ahhoz, hogy a tanulók magabiztosan tudjanak tájékozódni és választani a médiumok világában, hogy az értő, mérlegelő gondolkodással egyenrangú résztvevői lehessenek az új társadalmi színtereken zajló érintkezésnek. A tömegkommunikációs eszközök átalakulása, a közvetített információk mennyiségének folyamatos emelkedése és ellenőrizetlensége új kihívások elé állítja a jelen és jövő felnövekvő nemzedékeit. A tantárgy tanulása során a tanuló megismeri az egyes médiatípusok alapelveit, az általuk közvetített információk közötti szelekciós készség kialakítása, a nemzeti önazonosságtudat és a hazafias érzés megerősítése. A felelős, a családjáért és nemzeteért tenni akaró állampolgárrá váláshoz elengedhetetlen a médiaműveltség megszerzése. A mozgóképi alkotások a művészeti nevelés részeként erősítik a tanulók kulturális identitását, tágítják látókörüket és fejlesztik az esztétikai ismereteiket. A tantárgy tanítása szervesen kapcsolódik a digitális kultúra, a magyar nyelv és irodalom tantárgyakhoz, valamint a müvészetek tanulási területhez.

A tantárgy tartalmi elemei és fejlesztési céljai, feladatai között egyaránt szerepelnek müvészetpedagógiai, kommunikációs, technológiai, társadalomismereti, valamint az anyanyelvi kultúrával, a hazaszeretetre neveléssel kapcsolatos összetevők is.

\section{TeChNOLÓgIA}

A Technológia tanulási területen szerzett tanulási tapasztalatok közvetítésével a tanuló megismeri, hogy a korszakos jelentőségü technológiai találmányok miként változtatták meg a társadalom müködését és a társadalmat alkotó egyének és csoportok mindennapi életét. Tanulmányai eredményeként a tanuló a technológiák ismeretére és magabiztos alkalmazására tesz szert a különböző társas környezetekben, otthon, a munkahelyen és a szabadidős közösségekben. Az elsajátított tudás és tudásalkalmazás lehetővé teszi, hogy tájékozott fogyasztóvá és a termelésben kezdeményezően részt vevő vállalkozóvá váljon, valamint mérlegelni tudja a termékeknek és szolgáltatásoknak az életminőségre gyakorolt hatásait. Fontos cél, hogy a digitális technológiákat megfelelő színvonalon tudja alkalmazni munkájában, a mindennapi életben, továbbá ismerje ezeknek a globális kommunikációban betöltött szerepét, előnyeit, hátrányait és veszélyeit. A tanuló olyan ismeretekre és készségekre tesz szert, amelyek a tárgyak alkotásához, müködő szerkezetek létrehozásához vezető egyszerü és összetett munkafolyamatok végrehajtására teszik alkalmassá. A tanulási területen szerzett tudás a fejlett technológiai eszközök kialakítását megalapozó mérnöki és technológiai gondolkodás sajátos jellemzőinek és jelentőségének felismerését, valamint a technológiai újitások és a tudomány összekapcsolódásának megértését segíti elő. Az elsajátított ismeretek és készségek támogatják az olyan döntésekben való informált részvételt, amelyek a környezetre, a fenntarthatóságra, valamint a kultúra egészére vonatkozó következményekkel járnak. A tanuló tapasztalatot szerez a munka világában szerepet játszó fóbb készségek- 
ről, kompetenciákról, ezek fejlesztésének lehetöségeiröl és módjáról. A tanulási terület tantárgyi célkitűzései alapján megvalósított tanulás és tanítás olyan ismeretek megszerzését teszi lehetővé, amelyek kiterjednek a szakirányú tanulmányok és foglalkozások körére, hozzájárulva ezzel a választható foglalkozásokkal összefüggő jövőbeli elképzelések kialakulásához.

A Technológia tanulási terület a tanulás-tanítás során olyan tevékenységeket kínál, melyek kutatásvezérelt probléma-meghatározást és -megoldást igényelnek, új és ismeretlen anyagok felkutatását, szerkezetek működésének megismerését, technológiai fogalmak elsajátítását, készségek kialakítását és fejlesztését is lehetővé teszik, valamint produktumok létrehozását eredményezik. Ezek a tevékenységek hozzájárulnak az alkotó és mérlegelő gondolkodás fejlesztéséhez, valamint a vállalkozói és innovatív készségek megszerzéséhez. A tevékenységek által formálódó kompetenciák különösen nagy jelentőségre tesznek szert a középfokú és felsőfokú tanulmányok befejezését követően, amikor a tanulók az iskolát elhagyva a nemzeti és a globális gazdaság szereplőivé válnak, és bekapcsolódnak a munka világába.

A Technológia tanulási terület olyan tantárgyakat kapcsol egymáshoz, amelyek eltérő tartalommal és célrendszerrel rendelkeznek, de szemléletükben közös vonásokat jelenítenek meg: a digitális kultúra, valamint a technika és tervezés.

\section{VIII/1. DigItÁlis KULTÚRA}

A digitális kultúra tantárgy célja olyan naprakész ismeretek és készségek átadása és kialakítása, amelyek a tanulót az információs társadalom sikeres és hasznos tagjává teszik.

A tantárgy keretében fontos szerepet kap az algoritmizálás és kódolás, mivel elősegíti az olyan kompetenciák fejlesztését, mint a problémák digitális környezetben történő megoldása, a kreativitás, az együttmüködés és a logikus gondolkodás. A tantárgy tanulása-tanítása során kialakított kompetenciákat a tanuló képes lesz egyéb tudásterületeken is alkalmazni, megszerzi az alapvető digitális kompetenciákat.

A digitális kultúra tantárgy fontos feladata, hogy a tanuló képes legyen a felmerülö problémákat a digitális környezet eszközeivel megoldani, igénybe tudja venni az információs társadalom, e-Világ szolgáltatásait, eleget tudjon tenni az állampolgári kötelességeinek.

A foglalkozások tervezésében és lebonyolításában - az eltérő tudásszinttel rendelkező tanulók fejlesztése terén - nagy lehetőségeket kínál a digitális technológia alkalmazása. A jelenkor kihívásaira reagálva az iskolai tanulás és különösképpen a digitális kultúra tantárgy feladata, hogy támogassa a fiatalokat a technológiával való kapcsolattartásban, segítsen nekik kibővíteni és kiterjeszteni a technológia használatát a projektfeladatok teljesitésében, az önálló és csoportos tanulásban, az önképzésben, szem elött tartva a kreatív alkalmazás ösztönzését.

\section{VIII/2. TECHNIKA ÉS TERVEZÉS}

A technika és tervezés tantárgy a problémamegoldó gondolkodást, a saját tapasztalás útján történő ismeretszerzést helyezi a középpontba, melynek eszköze a tanórákon megvalósuló kreatív tervező és alkotó munka, a hagyományos kézműves és a legmodernebb digitális technológiák felhasználásával. A tantervben kiemelt szerepet kap a tanulni tudás, a tanultak alkalmazása, a problémamegoldáson alapuló alkotás. Ezt szolgálják a kínált tevékenységek, a nevelés, a kompetenciafejlesztés és a müveltségtartalom leírt rendszere, az egyes elemek arányos megjelenítése. 
A tantárgy keretében végzett tevékenységek elösegítik, hogy a tanuló aktív szerepkörben tervezési és végrehajtási készségeket alakítson ki az életében felmerülő komplex gyakorlati problémák megoldásához. A tanuló a tanulási folyamat során a közvetlen, mindennapi gyakorlati tevékenység végzése közben valódi anyagokból felhasználható produktumokat hoz létre, az életkorához illeszkedő, biztonságosan kezelhető szerszámok, eszközök segítségével.

A tantárgy felhasználja a közismereti tárgyak keretében már elsajátított ismeretek közül azokat, amelyek segíthetnek a mindennapi életben felmerülő problémák megoldásában. Olyan cselekvőképesség kialakítása a cél, amelynek mozgatója a felelősségérzet és az elköteleződés, alapja a megfelelő autonómia és nyitottság, a megoldási komplexitás.

A tantárgy struktúrájában rugalmas, cselekvésre építő, tanulóközpontú tanulásra ösztönöz. Az elsajátított tudás hozzájárul a mindennapi életben használható készségek kialakításához és elősegíti a munka világában történő alkalmazkodást.

\section{TeSTNEVELÉS ÉS EGÉSZSÉGFEJLESZTÉS}

A 21. századi emberkép egyik hangsúlyos összetevője, hogy az egyén aktív és cselekvő, ugyanakkor reflektív mérlegelésre képes. A cselekvő embert a mozgáshoz kapcsolódó helyes attitüdök, a fizikailag aktív életmód, önmaga reális elfogadása, a közösségi felelősségvállalással egybekötött autonómia, az újító kezdeményezésekre való nyitottság és a megbízható megoldások alkalmazásának képessége jellemzi.

A testileg és lelkileg egészséges ember az egészség állapotát, a harmonikus életet értékként éli meg. Az egészséges és harmonikus életvitelt megalapozó szokások a nevelés-oktatás egyes szakaszaiban a pedagógusok személyes példamutatásán keresztül alakulnak ki.

A mozgáshoz, mint alapkompetenciához kapcsolódó képességek, készségek, az adott szituációnak megfelelően mobilizálódó motoros képességek és készségek jelentik az alapját annak, hogy az adott egyén a társadalom aktív tagjává váljon, és az egész életen át tartó mozgásos cselekvési biztonság jellemezze.

A Testnevelés és egészségfejlesztés tanulási terület elsősorban a személyes és társas kompetencia fejlesztése révén járul hozzá az általános kompetenciákban és a nevelési-oktatási célokban megfogalmazott törekvések megvalósulásához. Hangsúlyos szerepet kapnak a szomatikus egészséggel, a társas-érzelmi jólléttel, a biztonsággal, az emberi kapcsolatokkal összefüggő kompetenciák. Az iskolai fejlesztés kiterjed a jó időszervezésre, a konstruktív kooperációra, valamint a testi jóllét és a motoros teljesítőképesség kialakítására is.

A tanulási terület testnevelés tantárgyának tanulása-tanítása során szerzett ismeretek, kialakított készségek és megfelelően formált attitűdök más általános kompetenciáknál is megjelennek. Példaként említhető a társadalmi részvétel és felelősségvállalás, ahol az iskola hozzásegíti a tanulót ahhoz, hogy toleránssá váljon a fogyatékossággal élők iránt. 